\title{
What is issue competition? Conflict, consensus and issue ownership in party competition
}

Isabelle Guinaudeau, European University Institute - Max Weber Programme

Simon Persico, Centre d'études européennes, Sciences Po Paris

\begin{abstract}
Empirical assessments of issue competition suffer from a fuzzy conception of what a "policy issue" is, but also from the scarcity of studies integrating both salience and positional perspectives. This article tries to provide a more precise definition of a "policy issue" and proposes a typology of electoral issues that takes into account the two sides of issue politicization - the decision whether to address an issue, and the decision to take a diverging or similar position on it. This typology allows distinguishing between proprietal, consensual and conflictual issues. This framework is applied to the example the politicization of EUrelated issues by British, French and German parties. Issue ownership, considered from the parties' perspective, appears to be both exceptional and ephemeral, with a decline of proprietal issues over time, which is reflected in parties' tendency to devote attention to the same issues than their competitors. Furthermore, regarding EU-related issues, we observe a primacy of consensus, especially amongst governing parties.
\end{abstract}


« The question whether a given problem poses a position- or valence-issue is a matter to be settled empirically and not on a priori logical grounds. " (Stokes, 1963, p.373)

\section{Introduction}

The literature on issue competition, concerned with how political parties use policy issues in electoral competition, is well established and has been growing in the last decade. The merits of this perspective - notably the salience (Budge and Farlie, 1983; Budge et al., 1987; Klingemann et al., 1994) and issue-ownership (Petrocik, 1996; Petrocik et al., 2003) theories - has been to underline that thematic emphasis is key to understand the dynamics of party competition. However, it seems to us that empirical assessments of issue competition suffer from a lack of conceptual precision and from the scarcity of studies that take both the classic positional and the more recent salience perspectives into account.

First of all, a review of the literature shows how impressionistic the uses of the term "issue" are. This label tends to cover fluctuating realities, with different degrees of inclusiveness, ranging from targeted policy problems, such as obesity or nuclear power plant safety, to policy sectors, e.g. health or electricity production, or even cross-sectorial policy fields, such as the Welfare state or environmental protection. As argued in more detail below, the implications of this imprecision reach far beyond definitional controversies, since the conclusions drawn from the same observations regarding issue salience, issue ownership or issue position may differ substantially according to the definition of a policy issue.

What is more, if scholarship on issue ownership has been powerful in the explanation of vote and electoral performances (Petrocik, 1996; Damore, 2004; Kaufmann, 2004; Aardal and van Wijnen, 2005), it has often been too static to account for party behaviour and 
strategies ${ }^{1}$. Empirical contributions show that ownership - understood as a party's monopoly over the politicization of an issue - is mostly contested, resulting in party systemic patterns of issue attention (e.g. Sigelman and Buell, 2004; Damore, 2004, 2005; Sulkin, 2005; Sides, 2006). Understanding electoral usages of issues therefore first requires analysing which issues parties try to push on the electoral agenda and whether certain issues underlie a particular party's monopoly (salience). Yet, as soon as competitors have taken up an issue, parties' positions become a relevant aspect as well. The competition over the electoral agenda and the definition of the desirable position should thus be studied together, in order to understand how they interplay.

This implies adopting a dynamic approach, in order to capture the fluctuations in parties' usages of issues, i.e. their attempt to push issues onto the agenda, their issue specialization, and the modalities of contestation of competitor's issue ownership. Describing such dynamics involves the development of categories suitable to characterize an issue's salience in the discourse of the different parties and its degree of conflict.

This article seeks to contribute to a more systematic knowledge of issue competition by proposing an operational definition of a "policy issue" (section 1). It offers a renewed typology of issues based on their salience and conflictuality, allowing a distinction between "proprietal", "consensual" and "conflictual" issues. We then lay down hypotheses on the rarity and ephemeral character of issue ownership, and on the use of proprietal, consensual and conflictual issues by challenger and mainstream parties (section 2). The last two sections present our mixed-method research design (3) and illustrate our argument from the

\footnotetext{
1 Although most of the existing literature studies issue ownership from the voters' perspective, this article focuses on ownership from the parties' perspective, i.e. the ability of a party to be the only one to address a given issue (Meguid, 2008).
} 
example of EU-related issues in France, Germany and the UK, between 1986 and 2009. This allows us to confirm the predominant role of party system features in shaping the use of policy issues: while proprietal issues are exceptional and ephemeral, we observe different usages of consensual and conflictual issues by mainstream and challenger parties. 


\section{What is a policy issue?}

In the literature about "issue competition", "issue ownership" or the "issue agenda" of elections, there is a remarkable lack of precision regarding the definition of a "policy issue". This concept covers very different realities from publication to publication, and sometimes even within a single study. In theoretical accounts, authors tend to always focus on the same issues, the typical examples of valence issues being systematically tired from the ones cited in Stoke's seminal article (1963): economic prosperity, corruption, inflation or the textbook example of the environment (Laver, 2001b; Katsanidou and Gemenis, 2010). Drawing from this a priori classification, salience theory has been tested on a large scale thanks to the Comparative Manifesto Project (CMP) data, through a coding of party manifestos where each coding category - internationalism, Welfare state expansion, national way of life, multiculturalism, law and order, labour groups, and so on - was conceived as a specific "issue" (e.g. Budge et al., 2001, p.76). Expert surveys, derived from a spatial (positional) conception of party competition in the Downsian tradition, also try to position parties on very broad "issues" such as immigration or European integration (see for example Huber and Inglehart, 1995; K. Benoit and Laver, 2006). More qualitative studies may define "issues" in a much narrower sense and tackle the politicization of strictly delimited policy problems (e.g. Culpepper, 2011, on the case of corporate governance).

The overview of the literature shows that three major conceptions of "issue" predominate. Issues can be broad (cross-sectoral) themes, such as welfare, prosperity, international relations or European integration (e.g., Marks and Steenbergen, 2004). They can also relate to policy sectors, such as health, pensions, transport, education, tax policy or immigration (e.g., Bale, 2003). They can finally refer to targeted policy problems, such as the invasion of 
Iraq, the fight against crime, the management of railways, or nationalizations (Green and S. B. Hobolt, 2008).

Beyond these divergences in the degree of precision or inclusiveness, "issues" alternatively represent policy objectives - less inflation, more income equality, more security, more prosperity, more morality... - or policy instruments - substantial decisions and legislation, spending, policy change. In other words, "issues" are sometimes specified (as the opposition between lower taxes and welfare spending for instance), or not (the issue of prosperity). At the same time, what is labelled "issues" in certain publications can be considered as "dimensions of conflict" (Veen, 2011) or as "cleavages" (Karvonen et al., 2001) elsewhere.

The implications of this imprecision reach far beyond definitional controversies. The interpretation drawn from the same observations may differ significantly depending on the definition used. For instance, the adoption of a broad definition of policy issue makes the identification of issue ownership very unlikely (Green-Pedersen and Blomqvist, 2004). The observation of a considerable overlap of issues in the electoral and legislative priorities of left and right parties on the basis of Comparative Agendas Project (CAP)'s data (Baumgartner et al., 2009; Persico et al., 2012) could thus be challenged when narrowing the unit of analysis, for example, when comparing the attention to subtopics instead of general topics. ${ }^{2}$ The characterization of an issue as valence or positional may also vary, since parties may agree on an objective, but not on the means to achieve it. European integration is a good example of these shortcomings, since the tendency to consider it as one single issue over which parties can adopt either pro- or anti-positions leads some scholars to assimilate

\footnotetext{
2 The CAP codebook is divided in 250 subtopics grouped in about 20 topics.
} 
parties with contrasted degrees and targets of contestation to a same "Eurosceptic" category.

In order to avoid these problems, we suggest a precise, narrow and operational definition of a "policy issue" that would facilitate systematic comparisons and the study of party competition. As we did not exclude the delimitation and specification of policy issues to be subject for party competition, we avoided any substantial assumption on the content and scope of issues. In this regard, we based this research on the following definition:

A question of public policy, as delimitated, defined and specified by political actors, possibly giving rise to one or several positions.

Examples of policy issues could be gay marriage, the construction of nuclear power plants, nationalizations of industries, the introduction of a minimum wage, and so on. Policy issues may be formulated more or less precisely (with for instance the mention of more or less concrete instruments of public policy), this degree of precision being to be assessed empirically by looking at political discourses. In other words, we claim that very general problems, such as the desirability for more immigration or environmental protection, may be called policy issues if political actors frame them in such a general way, but that they should not if they are addressed through the lens of a more precise problem. In this case, the discursive schemes may justify considering precise issues as part of one or more general policy themes, like family policy, environmental protection, industrial policy or welfare protection. Distinguishing between themes and issues seems crucial in order to clarify the debate and enable the structuration of a fruitful controversy, but also because the selection of a (more or less general) policy issue for politicizing a given theme is likely to be as subject to political competition as the definition of the desirable positions. 
Our argument can be exemplified by the theme of European integration, which is commonly presented as an "issue" (e.g. Kopecky and Mudde, 2002; Andersen and Evans, 2005; Hellstrom, 2008; De Vries and S. Hobolt, 2010), a "dimension" (Hix, 1998; Marks and Steenbergen, 2004) and even a "cleavage" (Kriesi et al., 2008). While the literature tends to reduce EU-related problems to an opposition between defence and critique of integration, we have proposed to approach the EU as a theme bundling 69 distinct issues in the sense defined above: Maastricht treaty, enlargement to Turkey, EU constitution, single currency... (Guinaudeau and Persico, forthcoming forthcoming; see also Veen, 2011). Reducing the range of EU-related problems to an antagonism between Europhiles and Eurosceptics leads to ignore competing specifications of European politics - focussed notably on single EU policies. It goes down to adopting the dominant specification constructed by mainstream party leaders in order to disqualify any critique of the EU. Instead, we suggest to distinguish the multiple EU-related issues emphasized by each party over time, which opens up the possibility to study how parties compete over the framing and the consensual vs. conflictual politicization of Europe.

\section{An integrated framework for describing and explaining issue competition.}

Following Stokes' advice quoted in the epigraph (1963, p.373), we argue that the study of issue competition should include all modalities of politicization of policy issues by political parties. This implies integrating the two main emphases of the issue-competition literature,

i.e., issue salience and issue conflict(Green-Pedersen, 2007, p.612)(Green-Pedersen, 2007)(Green-Pedersen, 2007: 612). This is in particular necessary for establishing the relative weight of conflict and consensus in issue competition over time. The following section 
introduces an integrated framework of issue competition and lays out two sets of hypotheses.

\section{a. Two faces of politicization}

\section{Salience, ownership and uptake}

First of all, as underlined by salience theory, issue politicization can be described in terms of salience, i.e. of the attention devoted by a party to an issue. This perspective scrutinizes the dynamics of agenda setting of policy issues, assuming that a minimum level of salience is necessary for an issue to be politicized. In this view, each party seeks to shape the electoral agenda by imposing its preferred issues. Parties have strong incentives to highlight the issues on which they enjoy an issue ownership in the eyes of the electorate ${ }^{3}$, a greater cohesion compared to other parties, or a position that is closest to the median position among voters (Budge, 2001; Laver, 2001b; Green-Pedersen, 2007).

The relevance of these parameters for explaining party behaviour has been questioned by empirical studies mobilizing the concepts of "issue uptake", "issue convergence" or "issue trespassing" which observe an important overlap in the electoral priorities of parties anchored in a same party system (Damore 2004 and 2005; Sulkin 2005; Sides 2006; Sigelman and Buell 2004; for the European context, see Brouard et al. 2012, see also GreenPedersen's contribution to this issue). While acknowledging the relevance of issue

\footnotetext{
3 Those are issues with which parties are widely and spontaneously associated, or on which they are acknowledged as the most competent (see Walgrave et al. 2012 for an overview of the issue-ownership literature).
} 
ownership for explaining the vote and electoral performances, these publications consider this perspective to be too static to account for parties' strategies.

In line with the definitional problems addressed in the previous section, a complementary critique may notice that the operationalization of studies of issue ownership implies that they tend to capture a more general thematic ownership exerted by parties on whole themes such as the environment, welfare, immigration, and so on. Such a monopoly is very unlikely given the cost of abandoning a large bundle of issues to another party. Instead of remaining silent on competitors' policy themes, parties are likely to privilege reframing them by politicizing other - more favourable - issues belonging to the same theme, possibly leading to an issue ownership (see Sides, 2006 for evidence, and Froio \& Castelli in this issue).

These discussions show that the determination of the degree of overlap vs. distinction of the issues politicized by competing parties is a major challenge to the issue competition literature. The salience of each issue to each party, as well as the number of parties devoting attention to it, thus appear to be crucial parameters of issue politicization.

\section{Positions and issue conflict}

As soon as an issue is salient to more than one party, the second important parameter of politicization comes into play, that is, the number of positions represented. Traditionally, electoral campaigns have been approached with spatial models contrasting parties according to their different positions on key issues (Downs, 1957). The abundant literature analysing actors' policy positions (see for example Laver, 2001a) shows the importance of 
this aspect of party competition. Yet, at least since Stokes, we know that not all issues give rise to distinct dimensions. Describing party competition thus requires to study whether and under which conditions policy issues give rise to conflict.

\section{On the necessity of studying jointly both faces of politicization}

If the concept of "valence issue" has had the merit to draw scholars' attention to consensual issues, a review of the literature inspired by Stokes' reflection reveal the limitations of the distinction between "positional" and "valence" issues for analysing issue competition in the two dimensions of salience and conflict. The ambiguity between these two dimensions lies in the very definition of "valence issues" as issues

"on which parties or leaders are differentiated not by what they advocate but by the degree to which they are linked in the public's mind with conditions or goals or symbols on which almost everyone approves or disapproves" (Stokes 1992: 143).

This definition refers both to the existence of an issue ownership (valence issues are owned by a party and should be salient above all in the discourse of this party) and to the consensual character of valence issues, suggesting that both characteristics tend to go hand in hand. Yet, this is empirically not necessarily the case (Pardos-Prado forthcoming) and there is no reason to postulate a priori a link between issue ownership and consensus. Several parties may indeed have the same position on the same issue, or a party may be associated with a conflictual issue in the eyes of the voters. Because of this problem, empirical studies of "valence issues" define them either in terms of issue ownership, or in terms of consensus, and end up focussing on heterogeneous issues. 
More generally, most studies of issue competition only focus on one of the two meanings of politicization - either politicization as emphasis or as conflictuality. This necessarily leads to a fragmentary knowledge: conflict may not be relevant in the case of non-salient issues; large similarities between parties' issue priorities may go along with a differentiation in terms of positions. For these reasons, we still know very little about the relative weight of consensual and positional issues and the rare hypotheses developed so far - for instance on the growing relevance of valence issues (Green, 2007) - would require empirical confirmation.

We thus propose a typology of policy issues crossing the two faces of politicization, constructed in order to help overcoming the confusion linked to the loose definition of the concepts of "policy issue", "politicization" and "valence", and structuring empirical work on issue competition and the share of consensus vs. conflict.

\section{A typology of policy issues}

Our typology of issues (Table 1) crosses the two faces of politicization. This simple classification allows distinguishing issues according to the number of parties making them salient and to the number of positions expressed. Issues that are politicized exclusively by one party (following Budge et al. 2001, p.153, we then speak of proprietal issues) will necessarily be subject to the monopoly of this party's position - which leaves the second field of the typology blank. Issues addressed by several parties may give rise to one (consensual issues) or several positions (conflictual issues). Put the other way around, conflictual issues characterized by the opposition of several positions can be demarcated 
from issues on which one position only is expressed, which may result either from an issueownership or from consensus. ${ }^{4}$

Although some issues might substantially lend themselves to consensus or conflict, the proprietal, consensual or conflictual character of an issue is not necessarily linked to intrinsic characteristics and the category in which each issue falls is likely to change along with context and party strategies. One of the main interests of our categorization is to enable the description of this type of change.

Table 1: A typology of policy issues

\begin{tabular}{|c|c|c|c|}
\cline { 3 - 4 } \multicolumn{2}{c|}{} & \multicolumn{2}{c|}{$\begin{array}{c}\text { Conflict: } \\
\text { Number of positions expressed }\end{array}$} \\
\cline { 3 - 4 } \multicolumn{2}{c|}{} & One & More than one \\
\hline $\begin{array}{c}\text { Salience: } \\
\text { Number of parties } \\
\text { addressing the issue }\end{array}$ & More than one & Proprietal & - \\
\cline { 2 - 4 } & & Consensual & Conflictual \\
\hline
\end{tabular}

Once a party sets an issue on the agenda, for instance the phasing-out of nuclear energy advocated by Green parties in numerous countries, the other parties have several possibilities. They can first ignore this new issue, making "nuclear phasing-out" the ownership of Green parties, and stress other issues that are more favourable electorally. They can alternatively uptake this issue, either by promoting the same position and making it a consensual issue, or by contesting this position, for instance with a discourse in favour of the status quo or the construction of new plants - the issue would then become conflictual.

\footnotetext{
4 The ambiguity of the concept of "valence issue" mentioned above is reflected in the fact that depending on the dimension of Stokes' definition emphasized, both proprietal and consensual issues may be considered as valence issues : the first because they underlie one party's issue ownership, the second because they foster party agreement on a certain goal.
} 
As mentioned above, preliminary work testing the "issue-uptake" hypothesis seems to indicate that issue salience largely follows systemic fluctuations. Parties tend to take up issues from other parties' discourse, so that issue ownership - in the sense of a party's monopoly over one issue ${ }^{5}$ - seems to be the exception rather than the rule. Even though we might observe the existence of proprietal issues, we expect issue ownership to be contested and ephemeral.

H1a: Issue ownership is exceptional. Most of party competition is about consensus or conflict.

H1b: Issue ownership is ephemeral. The number of proprietal issues declines over time.

\section{b. The dynamics of issue competition}

If issue ownership is limited, then most policy problems should be politicized as consensual or conflictual issues in the long run. Consensus may notably result from the affirmation of a general/national interest, from the existence of a wide cohesion around a position in society, or, more recently, from the perception of shrinking margins for manoeuvre due to constraints deriving from international competition, budget austerity, the scarcity of natural resources, or demographical evolutions (Mair, 2008). Many authors have argued that these trends affect conservative parties (Green, 2005), as well as social-democratic ones (Kitschelt, 1999; Bara and Budge, 2001). This tendency is in line with the process of "de-ideologisation" that characterizes the transformation of political parties in Western democracies, from bureaucratic mass parties to "catch-all" (Kirchheimer, 1966), "electoral-professional"

\footnotetext{
${ }^{5}$ Because we deal with party strategies - more than explaining vote or electoral performances - we focus here on a definition of issue ownership centred on party behaviour, and leave aside how far voters associate a party to an issue or consider a party to be the most competent for an issue. This "associative" and "competence issue ownership" (Walgrave et al. 2012), though, is likely to be relevant for understanding why some issues are proprietal, which may be studied by future research.
} 
(Panebianco, 1988), or "cartel" (Katz and Mair, 1995) parties. These changes probably do not affect all parties the same way. In particular, the party system and the status of parties are likely to shape their usages of issues.

On the one hand, mainstream parties having participated to cabinets (governing parties) enjoy a monopoly over democratic representation and access to power (Katz and Mair, 1996). Following Katz and Mair, their policy stances tend to be more influenced by the movement of "de-ideologization" and by the perception of growing constraints. Furthermore, mainstream parties have an incentive to reduce the space of policy competition in order to protect their primacy within the party system, notably by converging in terms of policy proposal (Blyth and Katz, 2005). In other words, governing parties have more incentives than their challengers to reduce competition by emphasizing consensual issues.

On the other hand, challenger parties are excluded from executive office and seek to challenge the governing parties' cartel and their subjects of consensus. We expect them to highlight the specificity of their policy stances towards voters, by setting new (originally proprietal) issues on the electoral agenda (Müller-Rommel, 1998) and by responding to eventual strategies of depoliticization on the part of mainstream parties (Meguid 2008) by radicalizing their position.

$\mathrm{H} 2 \mathrm{a}$ : Challenger parties politicize more proprietal issues than governing parties.

H2b: Governing parties politicize more consensual issues than challenger parties.

$\mathrm{H} 2 \mathrm{c}$ : Challenger parties politicize more conflictual issues than governing parties. 
The last two sections of this paper offer an exploratory test of our hypotheses in the case of EU-related issues in British, French and German party competition.

\section{Research design}

\section{a. Case selection}

\section{EU-related issues as a subset of policy issues}

The operationalization of our framework is complicated by the absence of an available database allowing to distinguish the three issue types, since existing data is either based on a loose definition of "policy issues" and/or does not provide a clear and inductive distinction between conflictual and consensual issues.

Faced with the necessity of collecting new data, we decided to focus on issues related to the general theme of European integration and EU policies. Previous scholarship has demonstrated that this theme encompasses numerous distinct issues (Guinaudeau and Persico, 2011; see also Höglinger, 2012). Some of them are in line with the historical cleavages (Lipset and Rokkan, 1967), on which mainstream governing parties acquired their primacy - e.g. the liberalization and privatization of public sectors, the implementation of a redistributive tax policy - while others are linked with "new politics" issues - e.g. EU enlargement, immigration policies, or climate change... - on which many challenger parties mobilize their voters (Franklin, 1992). This variety makes EU-related issues a challenging subset of policy issues enabling to explore how our framework can help accounting for party competition. 


\section{The period of study: 1986-2009}

Integrating the time dimension represents a major challenge to analyses of issue competition. Some studies differentiate long-term from short-term issue ownership (for instance Petrocik 1996; Walgrave \& de Swert 2007) and suggests that issues can switch from being proprietal to conflictual or consensual, and vice-versa. In order to be able to consider both short-term and long-term dynamics, we study more than two decades covering the years between 1986 and 2009, marked both by an acceleration of European integration (susceptible to make the related issues more salient over time) and by the rise and establishment of challenger parties in many West European party systems (Kriesi et al. 2008).

\section{Three party systems in comparison}

With regard to the criteria of feasibility, similarity of the country and level of economic development, along with variance in the number of parties, the existence of challengers, and the overall salience (or systemic salience) of EU-issues, we decided to study domestic party competition among British, French and German parliamentary parties. ${ }^{6}$

France is characterized by a high level of attention to EU-issues (Guinaudeau and Persico, 2011). Its multiparty system features three mainstream governing parties - a socialist party $(P S)$, a centre-right party (UDF) and a conservative party (RPR-UMP) - which have shared the

\footnotetext{
6 Parliamentary parties are parties that have had access to Parliament at least once between 1981 and 2010. This case selection explains why we left some parties out of our selection, such as the extreme-left parties in France (LO, NPA), the extreme right parties in Germany (NDP), or the Greens and the UKIP in the UK.
} 
Prime-Ministership since 1958. The Communist Party $(P C)$ has been a governing party, in junior positions within Socialist-led coalitions, ever since the legislative elections of 1981. The green party (Les Verts) has entered the Jospin's cabinet in 1997, thereby changing its status from challenger to governing party. Only one party, the far-right organization $(F N)$, has remained a challenger party over the whole period.

EU politics tend to be less debated in the German party system than in France. Besides the two mainstream governing parties, the Social-Democrats (SPD) and the Christian-Democrats (CDU), the Liberals (FDP) have participated to German cabinets since 1949, while the Greens became a governing party when they entered the Schröder government in 1997 . The postCommunist party (PDS - Die Linke), contrary to its French counterpart, has always remained a challenger party.

It is of great interest to compare these cases with the British one, characterized by an intermediary level of salience and a "two-and-a-half" party-system dominated by the Conservatives and the Labour Party ${ }^{7}$. By focussing on the period 1986-2009 and on national elections, our study purposely leaves aside two evolutions in British politics, namely the rise of the United Kingdom Independence Party, which has never accessed Westminster yet, and the participation of Liberal-Democrats to a Tories-led coalition since May 2010.

\section{b. Operationalization}

As argued in section 1, CMP data and expert surveys make strong assumptions regarding the nature of policy issues. While issues are predefined by the CMP codebook as consensual or

\footnotetext{
${ }^{7}$ The Liberal-Democrats have never accessed cabinet in the period of study. In this sense, it is studied here as a challenger party while acknowledging its specificities when compared to the challenger parties in other countries (notably in terms of ancienty and of their position on new politics).
} 
conflictual, expert surveys may lead to overestimate the weight of conflict by asking experts to locate parties along a series of continuums corresponding to different issues.

We use here an alternative coding procedure applied to manifestos presented at general elections by all parliamentary parties. Using a keyword search, we tracked the EU in each manifesto by capturing all sentences featuring the stem "euro" or the acronyms "EU" and "EEC". This procedure allowed us to gather a corpus covering all substantial propositions regarding EU treaties, institutions and policies, as well as policy claims formulated in a European perspective.

Table 2: Characteristics of the empirical corpus

\begin{tabular}{l|c} 
Total number of manifestos & 79 \\
\hline Total number of represented parties & 14 \\
\hline Total number of words & 113,916 \\
\hline Average proportion of manifestos dedicated to European issue & $8.7 \%$
\end{tabular}

The corpus was qualitatively and inductively analysed. We began by listing all issues that could be distinguished on the basis of the above definition of a "policy issue" in all manifestos. This led to the identification of no less than 69 issues, a list of which is reproduced in the Appendix $1 .^{8}$ Each manifesto was subsequently coded according to the presence or absence of each issue, which allowed us identifying "proprietal issues", i.e. issues tackled by one party only at a given election. ${ }^{9}$ When more than one party emphasised a given issue, we analysed the positions of all parties running for the election by comparing

\footnotetext{
8 This step of the analysis and the list of issues were described and analysed in a previous publication, cf. Guinaudeau \& Persico forthcoming.

${ }^{9}$ This operationalization of issue ownership as the politicization of an issue by one party exclusively can be seen as restrictive, as a significant difference in attention between one party and its competitors may already be interpreted as an issue ownership. This choice reflects the difficulty of establishing an absolute or relative threshold above which such a difference can be taken as significant, given the generally very low salience of each precise issue. The implications of this operationalization are discussed in the interpretation of our findings regarding the weight of proprietal issues.
} 
them in substance. Depending on the presence of a single or of several and distinct positions, this allowed us to establish the consensual or conflictual character of each issue.

In order to assess the relative weight of each issue type in the manifestos, the number of words granted to each issue was counted and put in relation to the total number of words of EU-related propositions in each manifesto. For each programme, this provided a measure of the relative salience of each issue and, more importantly, of the relative salience of each issue type - proprietal, consensual, or conflictual.

We tested our hypotheses using descriptive statistical analyses (hypotheses 1a and 1b), as well as t-tests between groups (hypotheses $1 b, 2 a$ and $2 b$ ).

\section{How British, French and German parties politicize the EU.}

Figure 1 displays the relative part of consensual, proprietal and conflictual issues in each manifesto. It allows us to draw many conclusions. First of all, the three issue types outlined above are present in almost all party manifestos. Contrary to what most of the literature on the politicization of Europe suggests, conflict over Europe appears to be limited: the average share of conflictual issues within a manifesto is $33.3 \%$, while consensual issues form a majority, with $60.7 \%$. Given the multidimensionality and the predominantly consensual character of EU-related issues, modelling party competition over Europe as a positioning along one or two dimensions of conflict therefore seems problematic. 
Figure 1: Consensual, proprietal and conflictual issues in party manifestos (in \%)

France

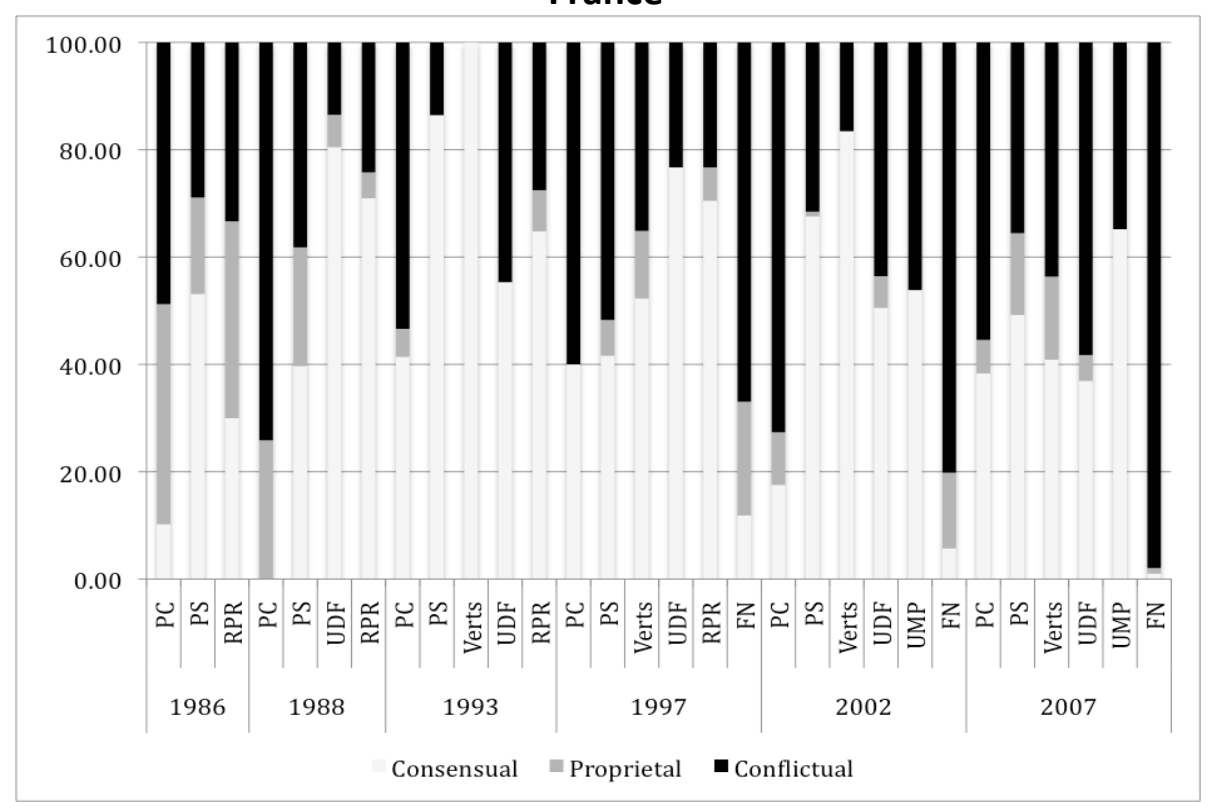

Germany

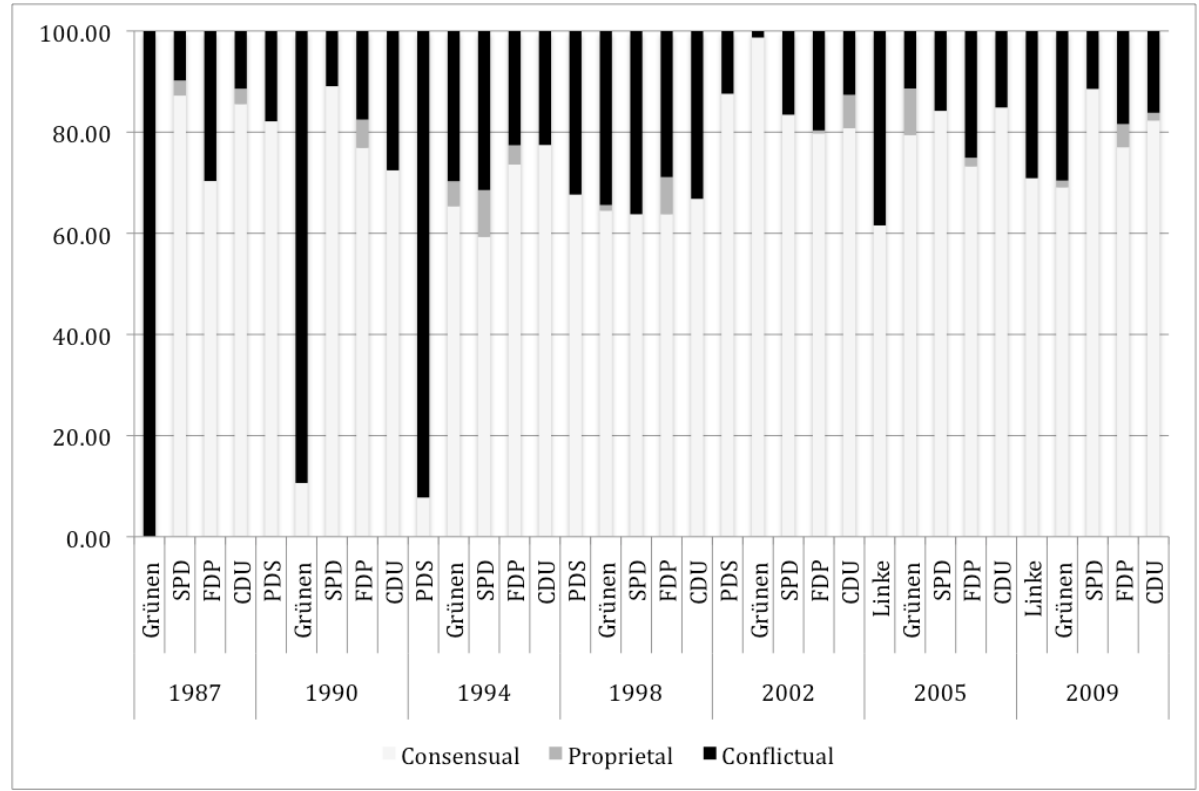




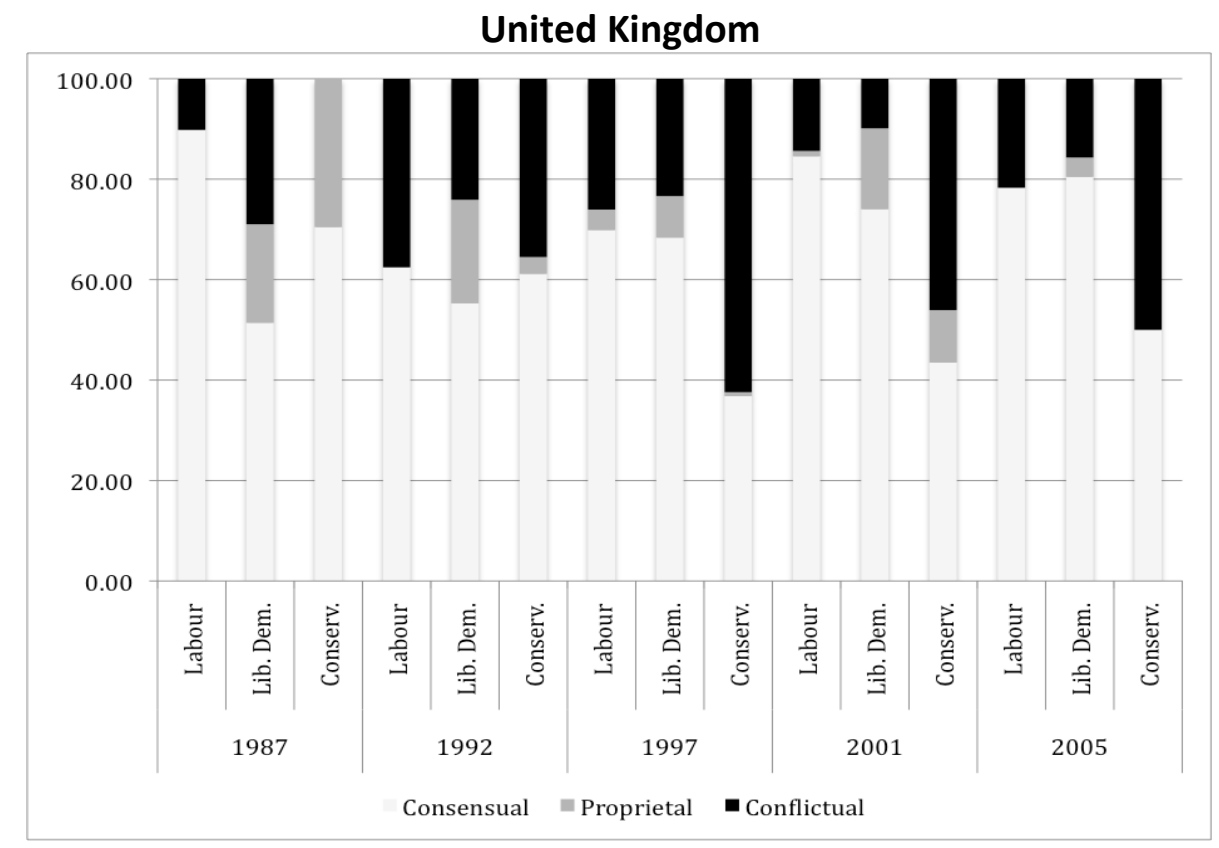

\section{a. An exceptional and ephemeral issue ownership}

Narrowing the definition of policy issues to specified questions of public policy is likely to increase the estimated weight of proprietal issues. Nonetheless, this type of issue represents only a tiny minority of problems addressed by parties ( $5.9 \%$ of manifestos on the average). There are clear inter-country differences regarding this share, since proprietal issues make out $11.5 \%$ of French parties' EU-related propositions, while this average percentage is smaller in the UK (7.9\%) and even more in Germany (only 1.9\%)s. These results seem to indicate that issue ownership is the exception rather than the rule, and proprietal issues appear to be more marginal (or contested) than suggested by salience theory: most parties contest their opponents' issue ownership by addressing this issue. Hypothesis $\mathrm{H} 1 \mathrm{a}$ is thus confirmed.

We have to admit that the marginality of proprietal issues might be less pronounced once they are operationalized less restrictively, by considering as proprietal any issue capturing significantly more attention on the part of one party than of its competitors. Yet, a closer 
look at the dynamics of politicization of proprietal issues corroborate the idea of a party system agenda constraining parties' freedom to emphasize their preferred issues and to ignore their competitors' issues.

First, the share of proprietal issues is declining over time, except in Germany where this share remains at a very modest level: the room left to proprietal issues by German parties does not exceed $5 \%$ on average, whereas it reached an average $31.1 \%$ in France in 1986, and $16.8 \%$ in the UK in 1987 . This ephemeral character of issue ownership confirms hypothesis $\mathrm{H} 1 \mathrm{~b}$ and substantiates the idea that parties tend to take up the issues of their opponents ${ }^{10}$.

Second, analysing the politicization of proprietal issues over time confirms such dynamics of uptake. One may quote the example of the issue of the European Social Chapter, which was only emphasised by the British Conservatives in 1988 and 1993, with strong arguments in favour of the opting-out, but became conflictual when New Labour began to be in favour of the adoption of this Social Chapter. The same goes with European employment policies, originally "owned" by the SPD but contested by FDP and CDU from 1998 on. Another example is the common home security policy, politicized only by the RPR until 1997, but strongly opposed by the National Front ever since. Contestation over an issue ownership can also turn proprietal issues into consensual ones, which has been the case of calls for a European Constitution in Germany (originally only defended by the FDP), for Erasmus exchanges and the protection of French cultural identity ('owned' by the RPR in the 1980s) and against market regulations in the UK (first politicized by the Conservatives).

\footnotetext{
10 We can here draw a link between issue ownership from the voters' perspective and issue ownership from the parties' perspective. Indeed, both of them are closely connected. Voters associate a party with an issue only if this party was, at one point in time, the only one to emphasise it. The associative issue ownership that exists, in the eye of voters, between Green parties and the environmental issue (Walgrave et al., forthcoming), directly relates to the fact that the Greens used to be the only one to campaign about environmental protection.
} 
A further striking characteristic of proprietal issues lies in their country-specific character. No party family seems to own an issue across borders and over time: EU support of free enterprise has long been owned by the German Liberals; the reinforcement of citizenship and voting rights for EU citizens has been an attribute of French Greens since 1997, while the FN are the only party addressing the Schengen agreement and freedom of movement (which it opposes). The Liberal Democrats have been the only British party to politicize the issue of transparency and publicity of Council meetings, and of defence of civil rights.

This qualitative analysis seems to indicate that, contrary to hypothesis $\mathrm{H} 2 \mathrm{a}$, proprietal issues are marginal in the manifestos of all parties, regardless of their governmental status. In order to test this hypothesis more rigorously, we compared the box-plots of the percentage of proprietal issues in the manifestos of challenger and governing parties. Figure 2 confirms the invalidation of $\mathrm{H} 2 \mathrm{a}$ by showing the weak difference, the median share of proprietal issues being even slightly higher in governing parties' manifestos ${ }^{11}$. It seems probable that some policy issues lend themselves more than others to be 'appropriated' by one party. Further research may clarify if our observation that challenger parties do not own more issues than governing parties is specific to the politicization of Europe, or valid also for other policy themes.

\footnotetext{
11 A two-sample t-test with unequal variance comparing these average shares confirms a non-significant difference.
} 
Figure 2: Percentage of proprietal issues in challenger and governing parties' manifestos

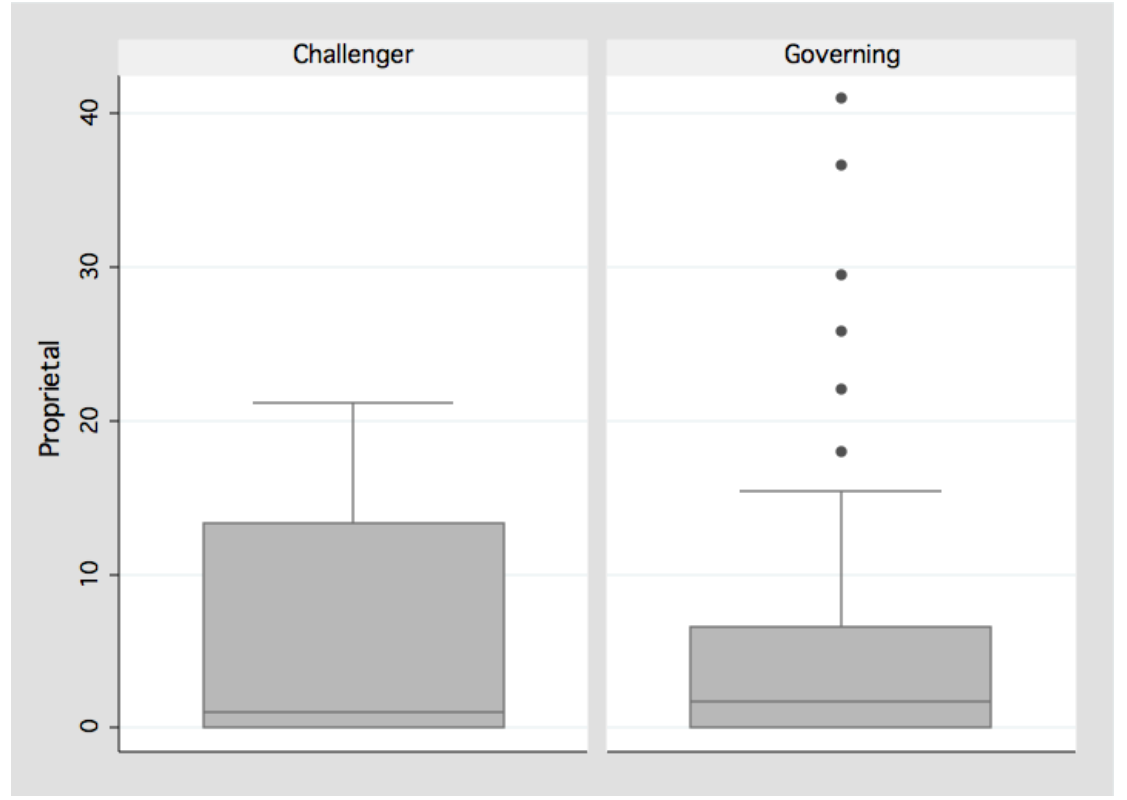

On the whole, proprietal issues are marginal in the programmes of all parties, as most of them are rapidly taken up by political competitors. The following analyses are dedicated to problems politicized by more than one party and to the relative share between conflictual and consensual issues among them.

\section{b. EU-politicization beyond conflict}

Most studies conceive EU-politicization as a positioning along an axis opposing Europhiles and Eurosceptics. Decomposing the theme of European politics into multiple issues and studying their degree of conflict in party manifestos reveals a different picture, marked by the clear primacy of consensual issues. This is particularly true in Germany and in the UK, where consensual issues make out respectively $70.2 \%$ and $65.1 \%$ of the sections dedicated to Europe in electoral manifestos. Consensual issues are also predominant in France, with an average of $47.9 \%$, even though the radically anti-European positions of the FN render many 
issues that are consensual among the other parties conflictual on the whole. This result may seem surprising with respect to well-known public controversies between parties, notably between the more pro-European British Labour and Liberal Democrats and their more sceptical Conservative opponent in the 1990s, or between French mainstream and challenger parties. While acknowledging the existence of such controversies, we observe that this type of confrontation structures only a minority of EU-related propositions in parties' official discourses. Faced with a highly fragmented opinion and with painful tradeoffs between policy-, vote- and office-related incentives, party leaders tend to emphasize facets on which the vast majority of members and leaders agree.

As for proprietal issues, consensual issues are highly country specific. The only common consensual issues across countries deal with the reinforcement of the powers of the European Parliament and of the national scrutiny over EU affairs, both very stable and popular topics. Beyond these issues, national specificities predominate: French parties expressing themselves on the following issues all stand for cultural diversity and socioeconomic interventionism at the European level, including common employment and industrial policy, harmonization of taxation and joint research programs. On the contrary, British manifestos claim for liberalization, market deregulation and a reform of the common agricultural policy. They also call for cooperation with the NATO and regularly promise not to adopt the euro without a previous referendum. German parties unanimously plaid for strict environmental standards, a common energy and transport policy, a federal EU respecting subsidiarity and basic rights, a common foreign policy, and the disarmament of Europe. Our observations indicate that consensual issues reflect country specific conceptions of Europe which correspond to the dominant perception of a national interest: a strong social and 
interventionist Europe in France, a grand market and a European pillar of NATO in the UK, and a federal, pacifist and ecological Europe in Germany.

\section{c. Consensual governing parties and conflictual challenger parties}

In line with hypothesis $\mathrm{H} 2 \mathrm{~b}$, the box-plots of the percentage of consensual issues in the manifestos of challenger parties, compared to governing parties, indicate a significant difference (Figure 3): governing parties politicize consensual issues more - with an average percentage of $64.1 \%$ - than challenger parties $-50.9 \%$. The two-sample t-test with unequal variance confirms a significant difference ${ }^{12}$. Theoretically, this result is in line with the deideologization and the cartelization perspectives which put, for different reasons, that mainstream parties are concerned with limiting conflict.

Figure 3: Percentage of consensual issues in the manifestos of challenger and governing parties

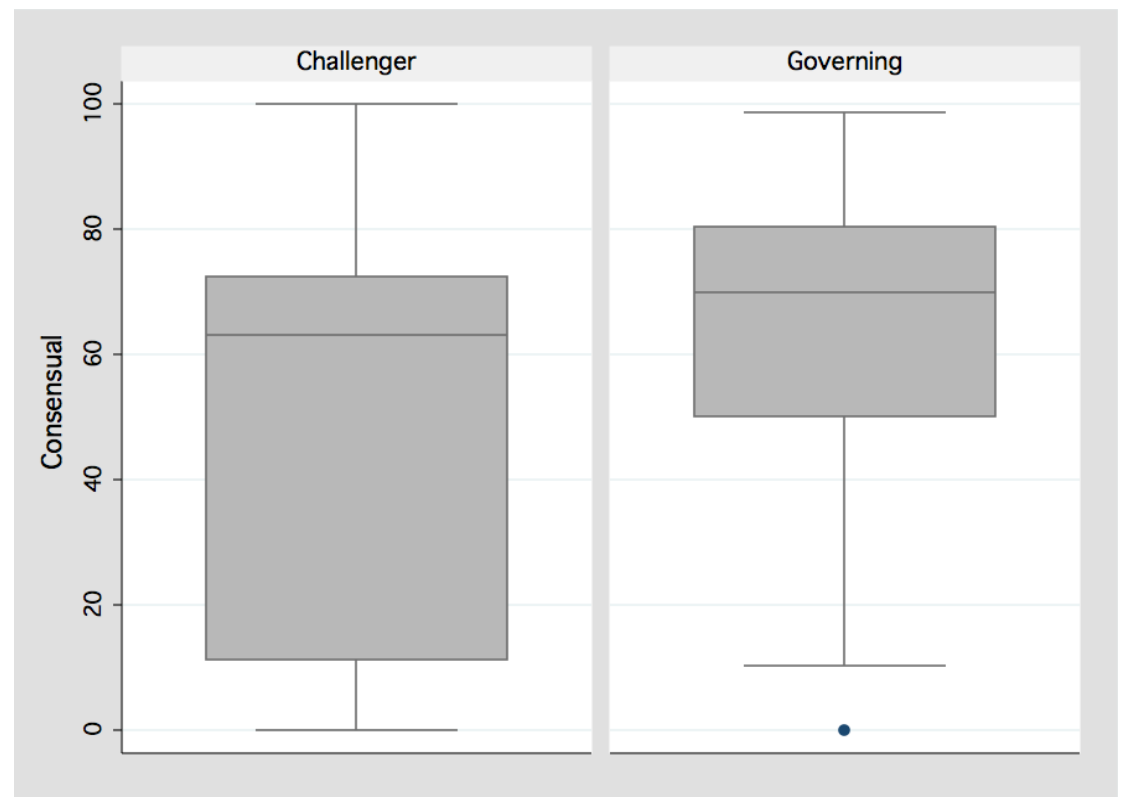

12 The probability of governing parties' average share of consensual issues being higher than challenger parties' one equals 0.05 . 
If only a minority of EU-related issues appears to be debated, the highest average share of conflictual issues is reached in France with $41.4 \%$ (a proportion close to the one of consensual issues), while it remains at a low level in Germany and in the UK, with 28.2 and $27.1 \%$ respectively.

A qualitative analysis of conflictual issues shows that patterns of opposition tend to reflect pre-existing lines of conflict. The most divisive issues fall into the classical socio-economic left-right opposition regarding the degree of desirable liberalization/deregulation vs. social protection which is present in the UK until 1997, in Germany, and above all in France. Other dimensions differ largely, reflecting country-specific and fluctuating variants of left-right opposition patterns. While the socio-economic divide heavily predominates in France, debates on police cooperation and European constitution are expressed in the UK and in Germany through the conflict between liberal and conservative parties regarding the balance between state authority and individual liberties. Germany is generally characterized by the weight of "new politics ", in particular by controversies over the EU foreign and security policy opposing the anti-militarist Greens and PDS-die Linke to the other parties. Moreover, the CDU rejects the other parties' position more or less in favour of the Turkish membership.

We also find distinct positions regarding what tends to be studied as the core of "the" European issue: the desirable level of European integration and the balance between national and supranational competences. British Liberal Democrats advocate for instance the delegation of additional competences to a stronger, federal EU with a strong parliament, a position rejected by the Conservatives. German parties disagree on Germany's contribution to the EU budget and France is divided between the hard Eurosceptic National 
Front - rejecting the principle of any increase in EU influence - and other parties. We would like to underline that these general issues regarding the principle of European integration are quantitatively very marginal in the corpus of EU-related manifesto sections. In other words, domestic parties are divided over the desirable degree of European integration but this is not what they usually stress when politicizing Europe.

The corollary of the observation of the bigger share of consensual issues in the manifestos of governing parties is the stronger attention dedicated by challenger parties to conflictual issues (42.9\%), when compared to governing parties $(30.0 \%)$, a significant difference confirmed by a two-sample t-test with unequal variance (Figure 4). ${ }^{13}$ This result confirms Hypothesis H2c.

Figure 4: Percentage of conflictual issues in challenger and governing parties' manifestos

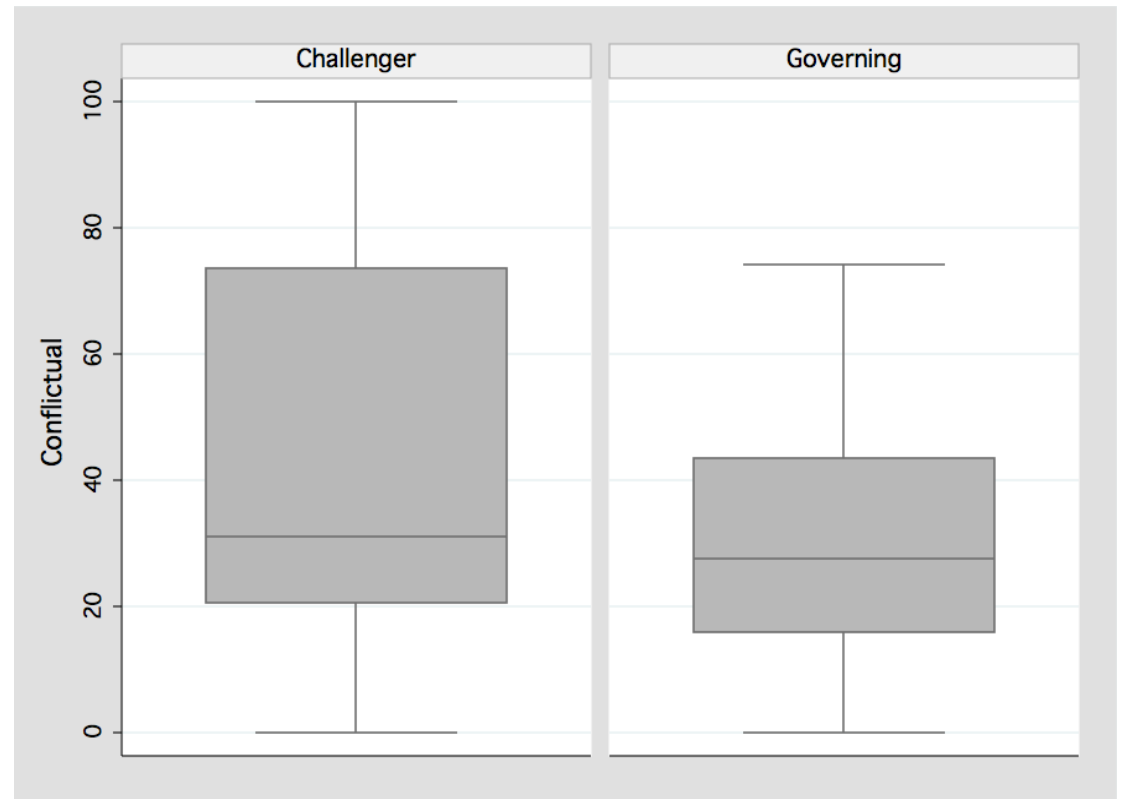

\footnotetext{
13 The probability of challenger parties' average share of conflictual issues being higher than governing parties' one equals 0.05 .
} 


\section{Conclusions}

We have argued that empirical assessments of issue competition suffer from lacking conceptual precision in the use of the concept of "policy issue", but also from the scarcity of studies integrating both the salience and the positional perspectives. We suggest narrowing the sense of "policy issue" to specified questions of public policy and propose a typology of policy issues, distinguishing proprietal, consensual and conflictual issues.

We hope that these conceptual clarifications will facilitate the empirical study of issue competition. More specifically, our analysis of the politicization of EU-related issues by British, French and German parties suggests possible applications of our framework. Our operationalization captures both the salience of each issue in each manifesto and the number of positions defended in each campaign, allowing to characterize each issue as proprietal, consensual or conflictual. A major advantage of this design is to capture fluctuations in partisan usages of issues, i.e. in the agenda-setting of new issues, parties' specialization in some issues, or in the modalities of contestation of competitors' issue ownership. This dynamic analysis shows that issue ownership is both exceptional and ephemeral, with a decline of proprietal issues over time, which is reflects parties' tendency to dedicate attention to the same issues. Furthermore, regarding EU-related issues, we observe a primacy of consensus, especially amongst governing parties. (Mainstream) politicians seem not to be interested in politicizing European integration and EU policies.

On the one hand, these findings have important implications regarding EU politicization. The predominance of consensual issues shades the relevance of the "absorption" (Harmsen 2005) and of the "inverted-U" hypotheses (e.g. Marks \& Steenbergen 2004) which both conceive EU politicization as intrinsically conflictual. In line with previous research, we 
acknowledge that mainstream governing parties have an interest to depoliticize the European theme, and especially the issue of the desirable degree of European integration. However, we contend that they do not depoliticize European integration only by adopting a moderate Europhile position, but also by emphasizing other EU-related issues which are either consensual, or easier to domesticate because they fit better into existing cleavages. By contrast, challenger parties have less interest in mobilizing on consensual themes and seek to politicize European integration by adopting more radical positions both on the principle of European integration and on more concrete, policy-related, issues.

On the other hand, and more generally, we hope that our typology may open the way for new developments in the study of issue competition, with a better integration of salience and positions along with a dynamic perspective: when and by which party has a given issue been set on the electoral agenda? Was it taken up by other parties, and how? Is the primacy of consensus in EU-related discourses specific, or does the politicization of other themes reflect a tendency towards de-ideologization? How far are party positions shaped by historical cleavages? Beyond the governmental status, how to explain to stronger propensity of some parties to politicize conflictual issues? These open questions may enable scholars to appreciate the wide potentialities of a more rigorous study of issue competition. 


\section{References}

Aardal, B. \& van Wijnen, P. (2005) 'Issue voting', in The European Voter. Oxford: Oxford University Press. pp. 192-213.

Andersen, R. \& Evans, J. (2005) The stability of French political space. French Politics. 3282301.

Bale, T. (2003) Cinderella and her Ugly Sisters: the Mainstream and Extreme Right in Europe's Bipolarising Party Systems. West European Politics. [Online] 26 (3), 67-90.

Bara, J. \& Budge, I. (2001) Party Policy and Ideology: Still New Labour? Parliamentary Affairs. [Online] 54 (4), 590-606.

Baumgartner, F. R. et al. (2009) Agenda-Setting Dynamics in France: Revisiting the Partisan Hypothesis. French Politics. 7 (2), 75-95.

Benoit, K. \& Laver, M. (2006) Party Policy in Modern Democracies. Routledge research in comparative politics (London) ; 19. , 1 vols. London: Routledge.

Blyth, M. \& Katz, R. S. (2005) From catch-all politics to cartelisation: the political economy of the cartel party. West European politics. 28 (1), 33-60.

Budge, I. et al. (1987) Ideology, strategy and party change : spatial analyses of post-war election programmes in 19 democracies. Cambridge: Cambridge university press.

Budge, I. et al. (2001) Mapping Policy Preferences: Estimates for Parties, Electors, and Governments, 1945-1998. , 1 vols. Oxford: Oxford university press.

Budge, I. (2001) Validating Party Policy Placements. British Journal of Political Science. 31 (1), 210-223.

Budge, I. \& Farlie, D. J. (1983) Explaining and predicting elections : issue effects and party strategies in twenty-three democracies. , 1 vols. London: G. Allen and Unwin.

Culpepper, P. D. (2011) Quiet politics and business power : corporate control in Europe and Japan. New York: Cambridge University Press.

Damore, D. F. (2005) Issue Convergence in Presidential Campaigns. Political Behavior. [Online] 27 (1), 71-97.

Damore, D. F. (2004) The Dynamics of Issue Ownership in Presidential Campaigns. Political Research Quarterly. [Online] 57 (3), 391 -397.

Downs, A. (1957) An economic theory of democracy. , 1 vols. New-York: Harper.

Franklin, M. (1992) 'The decline of cleavage politics', in Mark Franklin et al. (eds.) Electoral Change: Responses to Evolving Social and Attitudinal Structures in Western Countries. Cambridge: Cambridge University Press. pp. 381-402. 
Green, J. (2005) Conservative party rationality: Learning the lessons from the last election for the next. Journal of Elections, Public Opinion \& Parties. [Online] 15 (1), 111-127.

Green, J. (2007) When Voters and Parties Agree: Valence Issues and Party Competition. Political Studies. (55), 629-655.

Green, J. \& Hobolt, S. B. (2008) Owning the issue agenda: Party strategies and vote choices in British elections. Electoral Studies. (27), 460-476.

Green-Pedersen, C. (2007) The Growing Importance of Issue Competition: The Changing Nature of Party Competition in Western Europe. Political Studies. 55 (3), 607-628.

Green-Pedersen, C. \& Blomqvist, P. (2004) Defeat at Home? Issue-Ownership and Social Democratic Support in Scandinavia. Government and Opposition. [Online] 39 (4), 587-613.

Guinaudeau, I. \& Persico, S. (forthcoming) EU Politicization Beyond the Inverted-U. Systemic Salience and Multidimensionality.

Guinaudeau, I. \& Persico, S. (2011) 'L'Union européenne, un enjeu consensuel, propriétaire ou positionnel ? Les enjeux européens dans la compétition électorale en Allemagne, en France et au Royaume-Uni (1986-2009)', in Mathieu Petithomme (ed.) L'européanisation de la compétition politique nationale. Adaptations et résistances en perspective comparée. Presses universitaires de Grenoble Grenoble: pp. 73-96.

Hellstrom, J. (2008) Who leads, who follows? Re-examining the party-electorate linkages on European integration. Journal of European Public Policy. [Online] 15 (8), 1127-1144.

Hix, S. (1998) Elections, Parties and Institutional Design: A Comparative Perspective on European Union Democracy. West European Politics. 21 (3), 19-52.

Höglinger, D. (2012) Struggling with the intricate giant. The politicization of European integration in Western Europe. Zurich: Faculty of Arts of the University of Zurich.

Huber, J. D. \& Inglehart, R. (1995) Expert interpretation of party space and party locations in 42 societies. Party Politics. 1 (1), 73-111.

Karvonen, L. et al. (2001) Party systems and voter alignments revisited. Routledge advances in international relations and politics ; $12 ., 1$ vols. London: Routledge.

Katsanidou, A. \& Gemenis, K. (2010) 'Why the environment is not a textbook example of a valence issue?', in 2010 University of Essex: .

Katz, R. S. \& Mair, P. (1996) Cadre, Catch-All or Cartel? Party Politics. [Online] 2 (4), 525 534.

Katz, R. S. \& Mair, P. (1995) Changing models of party organization and party democracy: the emergence of the cartel party. Party politics. 1 (1), 5-28. 
Kaufmann, K. M. (2004) Disaggregating and Reexamining Issue Ownership and Voter Choice. Polity. 36 (2), 283-299.

Kirchheimer, O. (1966) 'The transformation of the Western European party systems', in Political parties and political development. Princeton: Princeton University Press. pp. 177-200.

Kitschelt, H. (1999) 'European Social Democracy between Political Economy and Electoral Competition', in Herbert Kitschelt et al. (eds.) Continuity and Change in Contemporary Capitalism. Cambridge: Cambridge University Press. pp. 317-345.

Klingemann, H.-D. et al. (1994) Parties, policies, and democracy. Boulder: Westview Press.

Kopecky, P. \& Mudde, C. (2002) The two sides of eurosceticism: party positions on European integration in East central Europe. European Union Politics. 3 (3), 297-326.

Kriesi, H. et al. (2008) West European politics in the age of globalization. Cambridge: Cambridge University Press.

Laver, M. (2001a) Estimating the Policy Positions of Political Actors. London: Routledge.

Laver, M. (2001b) 'Position and salience in the policies of political actors', in Michael Laver (ed.) Estimating the policy positions of political actors. London: Routledge. pp. 66-75.

Lipset, S. M. \& Rokkan, S. (1967) Party systems and voter alignments: cross-national perspectives. London: Collier Macmillan.

Mair, P. (2008) The Challenge to Party Government. West European Politics. [Online] 31 (12), 211-234.

Marks, G. W. \& Steenbergen, M. R. (2004) European integration and political conflict. Themes in European Governance. , 1 vols. Cambridge: Cambridge University Press.

Meguid, B. M. (2008) Party competition between unequals: Strategies and electoral fortunes in Western Europe. Cambridge University Press.

Müller-Rommel, F. (1998) The New Challengers: Greens and Right-Wing Populist Parties in Western Europe. European Review. [Online] 6 (02), 191-202.

Panebianco, A. (1988) Political parties: organization and power. Cambridge, MA: Cambridge University Press.

Persico, S. et al. (2012) Action publique et partis politiques. L'analyse de l'agenda législatif français entre 1981 et 2009. Gouvernement et Action Publique. 1 (1), 11-36.

Petrocik, J. R. et al. (2003) Issue Ownership and Presidential Campaigning, 1952-2000. Political Science Quarterly. 118 (4), 599-626.

Petrocik, J. R. (1996) Issue Ownership in Presidential Elections, with a 1980 Case Study. American Journal of Political Science. [Online] 40 (3), 825-850. 
Sides, J. (2006) The Origins of Campaign Agendas. British Journal of Political Science. [Online] 36 (03), 407-436.

Sigelman, L. \& Buell, E. H. (2004) Avoidance or Engagement? Issue Convergence in U.S. Presidential Campaigns, 1960-2000. American Journal of Political Science. [Online] 48 (4), 650-661.

Stokes, D. E. (1963) Spatial models of party competition. American Political Science Review. $57(2), 368-377$.

Sulkin, T. (2005) Issue Politics In Congress. Cambridge: Cambridge University Press.

Veen, T. (2011) The dimensionality and nature of conflict in European Union politics: On the characteristics of intergovernmental decision-making. European Union Politics. [Online] 12 (1), 65-86.

De Vries, C. E. \& Hobolt, S. (2010) 'Issue Entrepreneurship and The Dynamics of Multiparty Competition', in 22 April 2010 Chicago: . 


\section{Appendix 1: List of EU-related issues in British, French and German electoral manifestos (1986-2009)}

\begin{tabular}{|c|c|c|}
\hline 1 & \multirow{4}{*}{ Country in the EU } & Defence of national interests \\
\hline 2 & & Country's leadership in the EU \\
\hline 3 & & Creation of a ministry of Europe \\
\hline 4 & & Internal reforms to adapt to European integration \\
\hline 5 & \multirow{21}{*}{$\begin{array}{l}\text { European integration } \\
\text { and EU institutions }\end{array}$} & Principle of (further) European integration \\
\hline 6 & & Federalism vs. intergovernmentalism \\
\hline 7 & & Transfer of competences and sovereignty \\
\hline 8 & & Referendum over EU questions (Euro, Maastricht, ECT) \\
\hline 9 & & Amsterdam Treaty \\
\hline 10 & & Maastricht Treaty \\
\hline 11 & & European Constitution \\
\hline 12 & & Subsidiarity \\
\hline 13 & & National/parliamentary scrutiny over EU affairs \\
\hline 14 & & Majority voting in the Council \\
\hline 15 & & EU-budget (amount, country contributions, controls) \\
\hline 16 & & Creation of a mandate of EU-President \\
\hline 17 & & Transparency and publicity of Council \\
\hline 18 & & Extension of the powers of the European Parliament \\
\hline 19 & & Electoral system for European elections \\
\hline 20 & & Representation of Scotland, Wales and Ireland in the European Parliament \\
\hline 21 & & European Court of Justice \\
\hline 22 & & European citizenship \\
\hline 23 & & Voting right for citizens from Member States at municipal and European elections \\
\hline 24 & & European law academy \\
\hline 25 & & Free movement \\
\hline 26 & \multirow{4}{*}{ Enlargement } & Eastward enlargement \\
\hline 27 & & Enlargement to Turkey \\
\hline 28 & & Enlargement to Balkan countries \\
\hline 29 & & Enlargement to Russia, Ukraine, Belarus. \\
\hline 30 & \multirow{15}{*}{$\begin{array}{l}\text { State (macroeconomic) } \\
\text { intervention }\end{array}$} & Liberalization vs. public sector \\
\hline 31 & & Fair competition \& free market vs. industrial policy \\
\hline 32 & & Free trade vs. protectionism \\
\hline 33 & & Coordination of national macro-economic policies \\
\hline 34 & & EU support of enterprises \\
\hline 35 & & Regulation of finance markets \\
\hline 36 & & Market regulation: environmental and animal standards \\
\hline 37 & & Market regulation: others (patent, regulation of advertisement, consumer protection...) \\
\hline 38 & & EMS/ Monetary Union/Euro \\
\hline 39 & & Common tax policy \\
\hline 40 & & Common employment policy \\
\hline 41 & & Common social policies \\
\hline 42 & & Regional and structural policies \\
\hline 43 & & Joint R\&D programmes \\
\hline 44 & & Common infrastructure and transport policy \\
\hline 45 & \multirow{6}{*}{$\begin{array}{l}\text { Human rights, } \\
\text { immigration and home } \\
\text { security }\end{array}$} & Human rights policy \\
\hline 46 & & Data protection and civic rights \\
\hline 47 & & Anti-discrimination policy, minorities \\
\hline 48 & & Common immigration \& asylum policy \\
\hline 49 & & Common home security policy \\
\hline 50 & & Common Voluntary service \\
\hline 51 & \multirow{3}{*}{ Environment } & Animal welfare \\
\hline 52 & & Common energy policy \\
\hline 53 & & Common environmental policy \\
\hline 54 & \multirow{2}{*}{ Agriculture and fisheries } & Common agricultural policy \\
\hline 55 & & Common fishery policy \\
\hline 56 & \multirow{2}{*}{ Culture and Education } & Acknowledgement of diplomas across Europe \\
\hline 57 & & Common educational programmes \\
\hline
\end{tabular}




\begin{tabular}{|c|c|c|}
\hline 58 & & Exchange programs (Erasmus, etc.) \\
\hline 59 & & Cultural diversity \\
\hline 60 & & Common culture policy \\
\hline 61 & & Media \\
\hline 62 & & Sport \\
\hline 63 & \multirow{7}{*}{$\begin{array}{l}\text { EU foreign and security } \\
\text { policy }\end{array}$} & Common foreign and security policy \\
\hline 64 & & Common defence \\
\hline 65 & & Cooperation with NATO \\
\hline 66 & & Peace \\
\hline 67 & & Weapons \\
\hline 68 & & Arm Trade \\
\hline 69 & & Common development policy \\
\hline
\end{tabular}

